細管障害などによる急性腎障害がみられる。病 因としては 2 大別され, 原発性 (1 次性) と 2 次性がある. 前者の病型としては, 微小変化型 ネフローゼ (MCNS), 膜性腎症 $(\mathrm{MN})$, 巣状糸 球体硬化症（FGS）, 膜性増殖性糸球体腎炎 (MPGN) が代表的である。 また, 後者では糖尿 病性腎症, ループス腎炎, アミロイドーシスな ど様々な全身性疾患の腎合併症として起こる。 病型診断は腎生検によるが, 原疾患が明確な場 合には腎生検なしで病因は特定できる。症の 対症療法としては以下のようなものがある. 浮 腫に対して減塩と利尿薬(特にループ利尿薬)が 基本である. 蛋白尿に対しては原因療法のほか にレニンアンギオテンシン系阻害薬が有効な場
合がある．高脂血症に対してはスタチンが用い られることが多いが効果は明確でない。我が国 では原発性FGSに対してLDLアフェレーシスが 保険適用となっており，有効な症例が報告され ている。症に対する予防的抗凝固療法は推奨 されないが, 血栓症が発症した場合にはへパリ ンで治療を開始し以後はワーファリンで治療す る．原因療法としては以下の様である，MCNS はステロイドで完全寛解に至るが, 効果が明確 でない場合には他の病型を疑う。膜性腎症はス テロイド,カルシニューリン阻害薬, シクロフォ スファミドなどで治療する．最近では新たな免 疫抑制薬や生物製剤による治療が検討されてい る.

\title{
4. ステロイド性骨粗鬆症の病態と予防
}

九州大学大学院医学研究院病態制御内科学分野 高桝 涼一

生理量のステロイド（グルココルチコイド : GC) は骨芽細胞への分化を促進するが, 過剩量 のGCはステロイド性骨粗鬆症を発症させる. 骨 粗鬆症はステロイドの副作用として最も頻度が 高いので, その予防は重要である. ステロイド 性骨粗鬆症の発症要因は, GCの骨に対する直接 作用が主因である. 大量のGC投与時には二次性 副甲状腺機能立進症や下垂体抑制による性ステ ロイドの分泌抑制を惹起し, さらに, 骨粗鬆症 を促進させる. GCは間葉系幹細胞の脂肪細胞へ の分化促進により，骨分化を抑制する。また， コラーゲン合成やミネラル沈着を抑制する. RANKLを介して破骨細胞機能を立進させる. 近 年, 特に, 骨形成のWntシグナルをGCが抑制す ることが重要と考えられている. GCによるこれ らの作用が総和として骨粗鬆症を発症させる. わが国では日本骨代謝学会で「ステロイド性骨 粗鬆症の管理と治療のガイドライン」が 2004 年に策定された。その骨子は, 経ロステロイド
を 3 カ月以上使用中または使用予定で, 脆弱性 骨折，骨密度 (BMD) < 80\% (\%YAM), プレ ドニゾロン $5 \mathrm{mg} /$ 日以上, いずれかの場合は治療 を開始することである. 治療法はビスホスホネー 卜製剤を第 1 選択薬とし, 活性型ビタミン $\mathrm{D}_{3}$, ビタミン $\mathrm{K}_{2}$ を第 2 選択薬とする. 最近, 経口ビ スホスホネート投与者に顎骨壊死の発生が報告 されており，超高齢者やステロイド投与者など では骨代謝回転がかなり低下する可能性もあり, 欧米および我が国でも対応策が提唱されている. 閉経後骨粗鬆症の治療薬である選択的エストロ ゲン受容体モジュレーター (SERM) であるラロ キシフェンはステロイド性骨粗鬆症に対する臨 床効果のエビデンスが少ないため, ガイドライ ンでは治療選択薬として採用されていない，最 近, 我々も含めて, 小規模ながら無作為比較試 験においてステロイド性骨粗鬆症に対するラロ キシフェンの骨量減少防止効果が報告されてい る. 